\title{
Using agronomic biofortification to boost zinc, selenium, and iodine concentrations of food crops grown on the loess plateau in China
}

\author{
H. Mao ${ }^{1,2}$, J. Wang ${ }^{2,3}$, Z. Wang ${ }^{1,2,3 *}$, Y. Zan ${ }^{2,3}$, G. Lyons ${ }^{4}$, C. Zou ${ }^{5}$ \\ ${ }^{1}$ College of Natural Resources and Environment, Northwest A\&F University, Yangling, Shaanxi 712100, PR China. ${ }^{2}$ State \\ Key Laboratory of Crop Stress Biology in Arid Areas (Northwest A\&F University), Yangling, 712100, Shaanxi, China. ${ }^{3}$ Key \\ Laboratory of Plant Nutrition and Agri-environment in Northwest China, Ministry of Agriculture (College of Natural Resources \\ and Environment, Northwest A\&F University), Yangling 712100, Shaanxi, China. ${ }^{4}$ School of Agriculture, Food and Wine, \\ University of Adelaide, Waite Campus, PMB 1, Glen Osmond, South Australia 5064. ${ }^{5}$ Center for Resources, Environment and \\ Food Security, China Agricultural University, Beijing 100193, PR China. *Corresponding author: w-zhaohui@263.net
}

\begin{abstract}
Micronutrient malnutrition among humans is typically caused by micronutrient deficiency in soils and then staple food crops grown on these soils. In this study, field trials were conducted to investigate the biofortification of micronutrients in the edible parts of winter wheat, maize, soybean, potato, canola, and cabbage. Fertilizers of Se, $\mathrm{Zn}$ and I were applied to soil independently or together, while Se and $\mathrm{Zn}$ were sprayed as solution on winter wheat in another part of the trials. Selenium, when applied to the soil in the form of sodium selenate, whether alone or combined with $\mathrm{Zn}$ and/or I, was effective in increasing Se to around target levels in all of the tested crops. Selenium as sodium selenite was effective as a foliar application to winter wheat, increasing it from 25 to $312 \mu \mathrm{g} \mathrm{kg}^{-1}$ in wheat grain with $60 \mathrm{~g} \mathrm{Se} \mathrm{ha}^{-1}$. For Zn, soil-applied zinc sulphate was only found to be effective for increasing the $\mathrm{Zn}$ concentration in cabbage leaf and canola seed, with 35 and $61 \mathrm{mg} \mathrm{kg}^{-1}$, respectively, while foliar zinc sulphate application was effective in biofortifying winter wheat, increasing grain $\mathrm{Zn}$ from 20 to $30 \mathrm{mg} \mathrm{kg}^{-1}$. While for I, soilapplied potassium iodate was only effective in increasing I concentration in cabbage leaf, and biofortification of the other crops was not possible. The enhancements of Se, $\mathrm{Zn}$, and I concentration resulting from either the single or combined application of microelement fertilizers were similar. Therefore, agronomic biofortification of edible parts of various food crops with $\mathrm{Zn}, \mathrm{Se}$, and I can be an effective way to increase micronutrient concentrations, and the effectiveness depends on crop species, fertilizer forms and application methods.
\end{abstract}

Keywords: Biofortification, selenium, zinc, iodine, loess soil 


\section{Introduction}

About half of the world's population suffers from micronutrient malnutrition, including Se (selenium), $\mathrm{Zn}$ (zinc), and I (iodine), which is mainly associated with low dietary intake of micronutrients in diets with less diversity of food (Brown et al., 2001; Mayer et al., 2008). Biofortification of staple food crops with micronutrients through the use of agricultural tools is a cost-effective and sustainable approach to address this problem (Cakmak, 2008; White and Broadley, 2005). However, plant breeding, the most powerful agricultural approach, may not effectively work in regions where soils have very low plant-available pools of micronutrients due to very adverse soil chemical and physical conditions (Cakmak, 2008). Besides, finding sufficient and promising genotypic variation and maintaining the stability of targeted micronutrient traits across diverse types of environments may also be difficult (Lyons et al., 2005a). Under such circumstances, agronomic biofortification, including the use of micronutrient fertilizers, is an important complementary solution (White and Broadley, 2009).

Soils deficient in micronutrients including $\mathrm{Zn}, \mathrm{Se}$, and I, are widespread in China and a vast amount of soils have multi-microelement deficiency (Liu, 1994; Tan, 2004). Soils with low plant-available $\mathrm{Zn}\left(<1 \mathrm{mg} \mathrm{kg}^{-1}\right.$ DTPA-extractable Zn) occupy $40 \%$ of China's territory (Liu, 1994) and affects crop yields as well as human and animal health by reducing growth rates, causing stunting, and increasing susceptibility to diseases (Prasad, 2009). Iodine deficiency is also common, with endemic goiter occurring in 28 provinces and autonomous regions in China (Tan, 2004). In severely I-deficient areas with simultaneous soil Se deficiency, a severe cretinism problem marked by irreversible mental and growth retardation occurs at prevalence rates exceeding 1\% (Yang et al., 2007). Selenium deficiency mainly occurs in a belt from northeast to southwest China and represents an important factor in the occurrence of the arthritic condition called Kashin-Beck disease, which greatly reduces human well-being and working ability (Yang et al., 2007).
The micronutrients Se and I can be supplied in salt form to reduce the incidence of Kashin-Beck disease. However, the form of Se that naturally occurs in food may be more effective than inorganic Se used for this purpose (Bawa et al., 1992). Thus, the most efficient way to deal with this problem may be to improve the levels of these micronutrients in locally grown food crops by using an agronomic biofortification approach.

There are a range of crop biofortification approaches available. For $\mathrm{Zn}$ fertilization, foliar application seems to be more effective than soil application to reach the target concentration of $40 \mathrm{mg} \mathrm{kg}^{-1}$ in edible parts of crops (Cakmak et al., 2010b; Wang et al., 2012; Yilmaz et al., 1997). For Se, both soil and foliar applications of Se fertilizers are highly effective in increasing grain Se to the target concentration of 300 $\mu \mathrm{g} \mathrm{kg}^{-1}$ (Lyons et al., 2005b). The fertigation program in Northwestern China showed that I applied in irrigation water resulted in very positive effects on major food crop, human, and animal I status (Cao et al., 1994). Increasing I level in the edible parts of vegetables through a soil fertilization strategy also seemed effective (Dai et al., 2004), although the target I concentration of $500 \mu \mathrm{g} \mathrm{kg}^{-1}$ in grain is hard to reach (Mackowiak and Grossl, 1999).

It has been shown that soil- and/or foliar-applied $\mathrm{Se}, \mathrm{Zn}$ or I fertilizers have positive effects on the biofortification of different food crops (Cakmak et al., 2010a; Cao et al., 1994; Dai et al., 2004; Hasani et al., 2012; Lyons et al., 2005a). However, the effect of a combined foliar/soil application of micronutrients on grain $\mathrm{Zn}$, Se, and I in wheat grown under field conditions has not yet been reported. In the present study, we investigated the effects of soil and foliar applications of $\mathrm{Se}, \mathrm{Zn}$, and I on yield and concentrations of Se, $\mathrm{Zn}$, and I in edible parts of various food crops including wheat, maize, potato, cabbage, and soybean in the Loess Plateau, a typically $\mathrm{Zn}$, Se and I deficient area in China. 


\section{Materials and Methods}

\subsection{Experimental site}

The field trials were conducted at Yangmazhuang

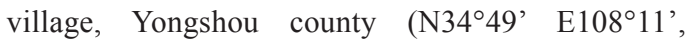
elevation=1127.76 m) in the central part of the Loess Plateau. Annual precipitation at the site is approximately $600 \mathrm{~mm}$, and more than $65 \%$ of the rainfall occurs between July and September. Three fields were selected in the trials due to the one plant season for wheat and maize per year. The soil in the experimental fields is a calcareous loam and its basic chemical properties are presented in Table 1. Field 1 had higher fertility of $\mathrm{OM}$ and nutrients except $\mathrm{N}$ and $\mathrm{P}$, but had lower total Se and higher available Se compared with fields 2 and 3 . The village has around 260 inhabitants predominantly subsisting on agriculture, and is identified as a suitable place to conduct micronutrient trials because it is a typical Kashin-Beck disease area, especially with around $12 \%(n=31)$ of elderly adults suffering from health problems.

\subsection{Experimental design}

Two field trials investigating the role of soil application of $\mathrm{Zn}, \mathrm{Se}$, and I fertilizers (field trial 1) and foliar-applied $\mathrm{Zn}$ and Se fertilizers (field trial 2) on the concentrations of $\mathrm{Zn}, \mathrm{Se}$, and I in edible parts of different food crops were conducted in this study.

\subsection{Field trial 1-Soil Application of Micronutrients}

In the first trial, spring maize (Zea mays L.), soybean (Glycine max L.), potato (Solanum tuberosum L.), cabbage (Brassica rapa L. Chinensis Group.), winter wheat (Triticum aestivum L.), and canola (Brassica napus L.) were used to study the effect of soil application of fertilizers. The cultivars used were Zhengdan 958 for spring maize, Qianjindou for soybean, Longshu 3 for potato, Siyueman for cabbage, Jinmai 47 for winter wheat, and Ganza 1 for canola.
The size of each plot was $16 \mathrm{~m}^{2}(4 \mathrm{~m} \times 4 \mathrm{~m})$, and plots with different treatments were arranged in a randomized block design with four replications for all crops in two fields. The usual local density of planting were used with $60,000,300,000,60,000$, 112,500 seedling ha $^{-1}$ for maize, soybean, potato and cabbage, respectively, while 2.25 and $150 \mathrm{~kg} \mathrm{ha}^{-1}$ for canola and winter wheat, respectively. Six treatments were constructed as follows: (1) with no $\mathrm{Se}, \mathrm{Zn}$, and I fertilizer application (Control); (2) with soil Se (in the form of selenate, Se) application; (3) soil Se (in the form of selenite, Se') application used on four crops except wheat and canola; (4) soil $\mathrm{Zn}$ (in the form of $\mathrm{ZnSO}_{4} \cdot 7 \mathrm{H}_{2} \mathrm{O}$ ) application; (5) soil I (in the form of $\mathrm{KIO}_{3}$ ) application, and (6) combined soil Se, Zn, and I application $(\mathrm{Se}+\mathrm{Zn}+\mathrm{I})$.

The application rates for $\mathrm{Se}, \mathrm{Zn}$, and I were 0.21 , 22.7, and $0.59 \mathrm{~kg} \mathrm{ha}^{-1}$ (as $0.50 \mathrm{~kg} \mathrm{Na}_{2} \mathrm{SeO}_{4} \mathrm{ha}^{-1}, 0.46$ $\mathrm{kg} \mathrm{Na}_{2} \mathrm{SeO}_{3} \mathrm{ha}^{-1}, 100 \mathrm{~kg} \mathrm{ZnSO}{ }_{4} \cdot 7 \mathrm{H}_{2} \mathrm{O}$ and $1 \mathrm{~kg} \mathrm{KIO}_{3}$, respectively), respectively. Nitrogen and phosphorus fertilizers (in the form of urea and diammonium phosphate) were applied on all of the plots. Nitrogen was applied at the rates of $160 \mathrm{~kg} \mathrm{ha}^{-1}$ for maize, wheat, canola, and cabbage, and $60 \mathrm{~kg} \mathrm{ha}^{-1}$ for soybean and potato. Phosphorus (in the form of $\mathrm{P}_{2} \mathrm{O}_{5}$ ) was applied on all of the plots at the rate of $100 \mathrm{~kg} \mathrm{ha}^{-1}$. Se, $\mathrm{Zn}$ and I fertilizers were sprayed on the soil surface in the solution form so that they could be homogeneously distributed in soil, and then were incorporated into the upper $20 \mathrm{~cm}$ of soil with the $\mathrm{N}$ and $\mathrm{P}$ fertilizers just before seeding using a harrow. These micronutrients are not currently applied to crops by farmers in this area.

The field experiments were conducted on the following dates: 9th of April (for potato); $23^{\text {rd }}$ of April (for spring maize and soybean); $6^{\text {th }}$ of May (for cabbage); $1^{\text {st }}$ of September (for canola); and $18^{\text {th }}$ of September (for winter wheat) in 2008. Harvesting (or sampling) was conducted on the following dates: $3^{\text {rd }}$ of August (for cabbage); 24 ${ }^{\text {th }}$ of August (for potato); and $2^{\text {nd }}$ of October (for spring maize and soybean) in $2008 ; 23^{\text {rd }}$ of May (for canola) and $12^{\text {th }}$ of June (for winter wheat) in 2009. 
Table 1. Basic chemical properties of air-dried loess soil in this study.

\begin{tabular}{|c|c|c|c|}
\hline Properties & $\begin{array}{c}\text { Field 1- } \\
\text { Maize/Potato/ } \\
\text { Cabbage/Soybean }\end{array}$ & $\begin{array}{c}\text { Field 2- } \\
\text { Wheat/Canola } \\
\text { (soil) }\end{array}$ & $\begin{array}{l}\text { Field 3- } \\
\text { Wheat } \\
\text { (foliar) }\end{array}$ \\
\hline $\mathrm{pH}\left(\mathrm{H}_{2} \mathrm{O}\right)$ & 8.16 & 8.21 & 8.12 \\
\hline Organic matter $\left(\mathrm{g} \mathrm{kg}^{-1}\right)$ & 13.6 & 12.2 & 12.1 \\
\hline Total nitrogen $\left(\mathrm{g} \mathrm{kg}^{-1}\right)$ & 0.86 & 0.81 & 0.88 \\
\hline Nitrate nitrogen (KCl-extractable) $\left(\mathrm{mg} \mathrm{kg}^{-1}\right)$ & 2.94 & 5.24 & 9.31 \\
\hline Ammonium nitrogen $(\mathrm{KCl}$-extractable $)\left(\mathrm{mg} \mathrm{kg}^{-1}\right)$ & 5.46 & 2.39 & 5.72 \\
\hline $\begin{array}{l}\text { Available phosphorus }\left(\mathrm{NaHCO}_{3} \text {-extractable) (mg }\right. \\
\left.\mathrm{kg}^{-1}\right)\end{array}$ & 6.63 & 15.9 & 17.9 \\
\hline $\begin{array}{l}\text { Available potassium }\left(\mathrm{NH}_{4} \mathrm{OAC} \text {-extractable) (mg }\right. \\
\left.\mathrm{kg}^{-1}\right)\end{array}$ & 102 & 86.3 & 98.5 \\
\hline Total zinc (Jackson method) $\left(\mathrm{mg} \mathrm{kg}^{-1}\right)$ & 69.3 & 62.8 & 64.1 \\
\hline Available zinc (DTPA-extractable)* $\left(\mathrm{mg} \mathrm{kg}^{-1}\right)$ & 0.73 & 0.78 & 0.73 \\
\hline Total selenium $\left(\mu \mathrm{g} \mathrm{kg}^{-1}\right)$ & 102 & 114 & 149 \\
\hline Available selenium $\left(\mathrm{KH}_{2} \mathrm{PO}_{4}\right.$-extractable $)\left(\mu \mathrm{g} \mathrm{kg}^{-1}\right)$ & 1.22 & 0.75 & 0.81 \\
\hline Total iodine $\left(\mathrm{mg} \mathrm{kg}^{-1}\right)$ & 1.710 & 1.501 & ** \\
\hline Available iodine (water-soluble) $\left(\mathrm{mg} \mathrm{kg}^{-1}\right)$ & 0.103 & 0.997 & $* *$ \\
\hline
\end{tabular}

${ }^{*}$ DTPA, diethylene triamine penta-acetic acid. In Field 1, Maize, potato, cabbage, and soybean experiments were conducted. In Field 2, wheat and canola soil application experiments were conducted. In Field 3, foliar Se and $\mathrm{Zn}$ application experiments on wheat were conducted. ${ }^{* *}$ No data obtained.

Crop management practices were the same as those used by local farmers. None of the crops were irrigated. Weeds were manually removed. No obvious water- or pest-related stresses were observed during the growing season.

\subsection{Field trial 2-Foliar Application of Se and Zn to Wheat}

To assess the effect of foliar application of Se and $\mathrm{Zn}$ to winter wheat (Triticum aestivum L.), a second field experiment was conducted using a local cultivar (Jinmai 47) at the same location as the field trial 1 . Similar to trial 1, a randomized block design with four replications was used. The wheat was planted on the $20^{\text {th }}$ of September 2008 at $150 \mathrm{~kg} \mathrm{ha}^{-1}$ on rows with $20-\mathrm{cm}$ spacing and harvested on the $10^{\text {th }}$ of June 2009. Foliar $\mathrm{Zn}$ and Se were applied at late anthesis stage
(Zadoks scale 48 to 49 , Zadoks et al. 1974). Zn rates were $0.00,0.23,0.45,0.68,0.91$, and $1.14 \mathrm{~kg} \mathrm{Zn} \mathrm{ha}^{-1}$ using $\mathrm{ZnSO}_{4} .7 \mathrm{H}_{2} \mathrm{O}$. Se rates were $0,4,20,30,46$, and $60 \mathrm{~g} \mathrm{Se} \mathrm{ha}^{-1}$ using selenite.

\subsection{Field sampling}

At harvest, five maize, soybean, potato, and canola plants were randomly sampled from each plot for nutrient analysis. Wheat plants were randomly sampled from four one-meter long rows. Sampled plants of maize, soybean, canola, and wheat were airdried and threshed, and those of potato were separated into shoots and tubers immediately after sampling. The fresh weight of shoots and tubers for potato, and the airdried weight for the other four crops were determined. All collected plant samples were first washed by tap water and then with distilled water. Thereafter, washed 
plant samples were dried to constant weight at $70{ }^{\circ} \mathrm{C}$ and stored for analysis. The remaining plants in each plot were harvested by hand and weighed to determine total biomass production and yield, which were expressed in dried weight at $70{ }^{\circ} \mathrm{C}$ for all crops.

\subsection{Chemical analysis}

Grain, tuber, and leaf samples collected from the trials were analyzed for Se (using inductively coupled plasma mass spectrometry (ICP-MS) following $\mathrm{HNO}_{3}-\mathrm{H}_{2} \mathrm{O}_{2}$ digestion) and $\mathrm{B}, \mathrm{Cu}, \mathrm{Fe}, \mathrm{Mn}, \mathrm{Zn}, \mathrm{P}, \mathrm{K}, \mathrm{S}, \mathrm{Ca}$, and $\mathrm{Mg}$ (using ICP-optical emission spectrometry (Radial CIROS)) (Zarcinas et al., 1987) at the University of Adelaide's Waite Analytical Services Laboratory, Adelaide, South Australia. Iodine concentrations of the samples were measured at the RJ Hill Laboratories Ltd., Hamilton, New Zealand, using ICP-MS. The nitrogen concentration of the samples was determined using the Kjeldahl method after digestion of the samples with $\mathrm{H}_{2} \mathrm{SO}_{4}-\mathrm{H}_{2} \mathrm{O}_{2}$ (Ercoli et al., 2011). Sample analyses were reported as the mean of four replications. The macro- and micronutrient concentrations in edible parts were expressed on a dry weight basis for all crops.

\subsection{Statistical analysis}

Analyses of variance were conducted using PASW statistics 17.0 Edition. The level of significance was 0.05 .

\section{Results}

\subsection{Field trial 1}

Despite large variation in mean yield per treatment, there was also a high level of variability in yield (CV 5.3-27.0\%) and the field trials with soil applications showed that all of the micronutrient applications had no effect on the yield of tested crop plants (Table 2). The average yields obtained (per ha) were 4101 and $9530 \mathrm{~kg}$ grain for wheat and maize, 1413 and $2079 \mathrm{~kg}$ seed for soybean and canola, $3298 \mathrm{~kg}$ tuber for potato, and 2399 $\mathrm{kg}$ biomass for cabbage (Table 2).
Both forms of Se were effective at increasing $\mathrm{Se}$ concentration in edible parts, but Se treatment was more effective than Se' (Table 3). In the selenate form, the Se increases compared to the control treatment were 78 to 228 fold, and the Se application at $1 \mathrm{~g}$ ha ${ }^{-1}$ increased the Se concentration by $17.4 \mu \mathrm{g} \mathrm{kg}^{-1}$ in wheat grain, $8.6 \mu \mathrm{g} \mathrm{kg}^{-1}$ in maize grain, $17.3 \mu \mathrm{g} \mathrm{kg}^{-1}$ in soybean seed, $10.2 \mu \mathrm{g} \mathrm{kg}^{-1}$ in potato tuber, $4.1 \mu \mathrm{g}$ $\mathrm{kg}^{-1}$ in canola seed, and $76.8 \mu \mathrm{g} \mathrm{kg}^{-1}$ in cabbage leaf, with the Se biofortification target of $300 \mu \mathrm{g} \mathrm{kg}^{-1} \mathrm{DW}$ reached at $16,34,15,28,71$ and $3 \mathrm{~g} \mathrm{ha}^{-1}$, respectively for these crops.

In selenite form, the corresponding increases were lower and only 5 to 14 fold. The Se application of $1 \mathrm{~g} \mathrm{ha}^{-1}$ increased the Se concentration by $0.2 \mu \mathrm{g}$ $\mathrm{kg}^{-1}$ for maize, $1.2 \mu \mathrm{g} \mathrm{kg}^{-1}$ for soybean, $0.9 \mu \mathrm{g} \mathrm{kg}^{-1}$ for potato, and $6.5 \mu \mathrm{g} \mathrm{kg}^{-1}$ for cabbage, with the Se biofortification target reached at 1445, 212, 317 and $31 \mathrm{~g} \mathrm{ha}^{-1}$, respectively. No significant difference was detected between the increasing effect of Se on the edible parts of all tested crops in Se-only treatment and $\mathrm{Se}+\mathrm{Zn}+\mathrm{I}$ treatment.

Soil $\mathrm{Zn}$ application in the form of zinc sulphate at 22.7 $\mathrm{kg} \mathrm{ha}^{-1}$ at planting was effective for biofortification of $\mathrm{Zn}$ concentration in cabbage leaves and canola seed (Table 3). In the Zn-treated soil, the Zn concentration in the cabbage leaf was increased by 2 fold and 0.3 fold in canola seed, and $\mathrm{Zn}$ application of $1 \mathrm{~kg} \mathrm{ha}^{-1}$ increased their $\mathrm{Zn}$ concentrations respectively by 0.3 and $1.8 \mathrm{mg}$ $\mathrm{kg}^{-1}$, with the $\mathrm{Zn}$ biofortification target of $40 \mathrm{mg} \mathrm{kg}^{-1}$ reached correspondingly at 40 and $11 \mathrm{~kg} \mathrm{ha}^{-1}$. In contrast to cabbage and canola, $\mathrm{Zn}$ biofortification did not cause a significant increase in $\mathrm{Zn}$ concentration in wheat grain, maize grain, soybean seed, and potato tuber. The change in $\mathrm{Zn}$ concentration in the edible parts of all the tested crops caused by $\mathrm{Zn}$ treatment was similar to that by the $\mathrm{Se}+\mathrm{Zn}+\mathrm{I}$ treatment.

Results of I soil application in the form of potassium iodate at $590 \mathrm{~g} \mathrm{ha}^{-1}$ at planting were similar to that of $\mathrm{Zn}$ (Table 3), showing significantly increased I concentration only in cabbage. 
Table 2. Effects of soil applied Se, Zn, I, and their combinations on grain/seed/tuber yield of crops in Trial 1.

\begin{tabular}{lllllll}
\hline & \multicolumn{5}{c}{ Yield $\left(\mathbf{k g ~ h a}^{-1}\right)$} \\
\cline { 2 - 7 } Treatments & Wheat & Maize & Soybean & $\begin{array}{l}\text { Potato } \\
(\mathbf{D W})\end{array}$ & Canola & $\begin{array}{l}\text { Cabbage } \\
\text { (DW) }\end{array}$ \\
\cline { 2 - 7 } & & & & & & \\
\hline Control & $4285(10.1)$ & $9792(4.6)$ & $1103(11.1)$ & $3477(16.3)$ & $2133(14.7)$ & $2675(20.4)$ \\
Se (as & & & & & & \\
selenate) & $3991(5.3)$ & $9705(4.5)$ & $1452(19.7)$ & $3071(22.1)$ & $1558(22.5)$ & $3205(18.9)$ \\
Se' (as & & & & & & \\
selenite) & & $9536(6.8)$ & $1192(26.9)$ & $3461(9.5)$ & $*$ & $3644(13.9)$ \\
Zn & $4167(14.1)$ & $9502(10.5)$ & $1749(27.0)$ & $3424(18.0)$ & $2604(12.8)$ & $1841(15.4)$ \\
I & $3957(9.7)$ & $9432(8.4)$ & $1636(21.6)$ & $3191(23.4)$ & $2283(16.1)$ & $1441(25.2)$ \\
Se+Zn+I & $4104(16.8)$ & $9213(8.4)$ & $1344(24.6)$ & $3161(13.8)$ & $1815(20.3)$ & $1587(14.7)$ \\
\hline
\end{tabular}

"No Se' (as selenite) treatment for wheat and canola. There are no significant difference between treatments $(p>0.05)$. Data are showed as means and figures in parentheses are $\mathrm{CV} \%$ of four replications for each treatment.

Soil application of I exhibited a 2 -fold increase in cabbage leaf I concentration from $580 \mu \mathrm{g} \mathrm{kg}^{-1}$ to 1150 $\mu \mathrm{g} \mathrm{kg}^{-1}$, and I application of $1 \mathrm{~g} \mathrm{ha}^{-1}$ increased the leaf I concentration by $1.1 \mu \mathrm{g} \mathrm{kg}^{-1}$, with the I biofortification target of $500 \mu \mathrm{g} \mathrm{kg}^{-1}$ reached without I application. No significant increases in I concentrations of other tested crops were observed (Table 3). The change in I concentration from the I fertilizer was statistically identical to those of the I and $\mathrm{Se}+\mathrm{Zn}+\mathrm{I}$ treatments.

Soil application of Se, $\mathrm{Zn}$, and I was not effective in increasing the concentrations of other micronutrients (Table 4) or macronutrients (data not shown) in the edible parts of the tested crops. Data were showed with $\mathrm{Se}+\mathrm{Zn}+\mathrm{I}$ treatments only. Cabbage contains high concentrations of $\mathrm{Fe}$ and $\mathrm{Ca}$, whereas soybean seed contains high concentration of $\mathrm{Fe}, \mathrm{Cu}$, and $\mathrm{Zn}$.

\subsection{Field trial 2}

Foliar application of sodium selenite and zinc sulphate on winter wheat at late-booting stage at rates of up to $60 \mathrm{~g} \mathrm{ha}^{-1}$ and $1.14 \mathrm{~kg} \mathrm{ha}^{-1}$ showed no significant effects on the biomass or grain yield (Table 5). The wheat biomass ranged from $8737 \mathrm{~kg} \mathrm{ha}^{-1}$ to $10080 \mathrm{~kg} \mathrm{ha}^{-1}$, whereas the grain yield ranged from $3658 \mathrm{~kg} \mathrm{ha}^{-1}$ to $4278 \mathrm{~kg} \mathrm{ha}^{-1}$ (Table 5). The average values of wheat biomass and grain yield were 9481 and $3999 \mathrm{~kg} \mathrm{ha}^{-1}$, respectively.

Foliar applications of Se and $\mathrm{Zn}$ were both highly effective in the biofortification of wheat (Figure 1). Foliar application of Se at rates of $4 \mathrm{~g} \mathrm{ha}^{-1}$ to $60 \mathrm{~g}$ $\mathrm{ha}^{-1}$ linearly increased the grain Se concentration, and application of Se at the rate of $1 \mathrm{~g} \mathrm{ha}^{-1}$ increased the Se concentration in wheat grain by $4.6 \mu \mathrm{g} \mathrm{kg}^{-1}$, and the grain Se target of $300 \mu \mathrm{g} \mathrm{kg}^{-1}$ was able to be reached at the foliar application rate of $59 \mathrm{~g} \mathrm{ha}^{-1}$ (Figure 1). Whereas, grain $\mathrm{Zn}$ concentration was increased with the foliar $\mathrm{Zn}$ application rate in a quadratic line, with the maximum grain $\mathrm{Zn}$ of $30 \mathrm{mg}$ $\mathrm{kg}^{-1}$ reached at $1.1 \mathrm{~kg} \mathrm{ha}^{-1}$ (Figure 1). This indicated that the Se and $\mathrm{Zn}$ concentrations in wheat grain could be simultaneously enhanced by the foliar application of Se and $\mathrm{Zn}$, although the $\mathrm{Zn}$ concentration was still lower than the recommended value of $40 \mathrm{mg} \mathrm{kg}^{-1}$. $\mathrm{Zn}$ or Se application had no effect on the concentrations of macronutrients or other micronutrients in wheat grain (data not shown). 
Table 3. Micronutrient concentration in edible crop parts after soil application of Se, Zn, and I at planting in Trial 1.

\begin{tabular}{|c|c|c|c|c|c|c|}
\hline \multirow{2}{*}{ Treatments } & \multicolumn{6}{|c|}{ Micronutrient Concentration } \\
\hline & Wheat & Maize & Soybean & Potato & Canola & Cabbage \\
\hline \multicolumn{7}{|c|}{ Se $\left(\mu \mathrm{g} \mathrm{kg}^{-1}\right)$} \\
\hline Control & $16 \mathrm{~b}$ & $11 \mathrm{c}$ & $46 \mathrm{c}$ & $15 \mathrm{c}$ & $11 \mathrm{c}$ & $97 \mathrm{c}$ \\
\hline Se (as selenate) & 3667 a & 1807 a & 3682 a & 2149 a & $865 \mathrm{a}$ & $16234 \mathrm{a}$ \\
\hline Se' (as selenite) & $*$ & $63 \mathrm{~b}$ & $297 \mathrm{~b}$ & $196 \mathrm{~b}$ & $*$ & $1469 \mathrm{~b}$ \\
\hline $\begin{array}{l}\mathrm{Se}+\mathrm{Zn}+\mathrm{I} \\
\text { (Se as selenate) }\end{array}$ & 4493 a & 1667 a & $2228 \mathrm{a}$ & $1701 \mathrm{a}$ & $700 \mathrm{a}$ & $19161 \mathrm{a}$ \\
\hline \multicolumn{7}{|c|}{$\mathrm{Zn}\left(\mathrm{mg} \mathrm{kg}^{-1}\right)$} \\
\hline Control & $15 \mathrm{a}$ & $16 \mathrm{a}$ & $57 \mathrm{a}$ & $13 \mathrm{a}$ & $28 \mathrm{~b}$ & $20 \mathrm{~b}$ \\
\hline Zn & $16 \mathrm{a}$ & $17 \mathrm{a}$ & $59 \mathrm{a}$ & $15 \mathrm{a}$ & $35 \mathrm{a}$ & $61 \mathrm{a}$ \\
\hline $\begin{array}{l}\mathrm{Se}+\mathrm{Zn}+\mathrm{I} \\
\text { (Se as selenate) }\end{array}$ & $16 \mathrm{a}$ & $18 \mathrm{a}$ & 59 a & $13 \mathrm{a}$ & $36 \mathrm{a}$ & $48 \mathrm{a}$ \\
\hline \multicolumn{7}{|c|}{ I $\left(\mu \mathrm{g} \mathrm{kg}{ }^{-1}\right)$} \\
\hline Control & $11 \mathrm{a}$ & $11 \mathrm{a}$ & $13 \mathrm{a}$ & $63 \mathrm{a}$ & $975 \mathrm{a}$ & $580 \mathrm{~b}$ \\
\hline I & $21 \mathrm{a}$ & $20 \mathrm{a}$ & $19 \mathrm{a}$ & $58 \mathrm{a}$ & $890 \mathrm{a}$ & $1150 \mathrm{a}$ \\
\hline $\begin{array}{l}\mathrm{Se}+\mathrm{Zn}+\mathrm{I} \\
\text { (Se as selenate) }\end{array}$ & $20 \mathrm{a}$ & $18 \mathrm{a}$ & $18 \mathrm{a}$ & $59 \mathrm{a}$ & $875 a$ & $1150 \mathrm{a}$ \\
\hline
\end{tabular}

"No Se (as selenite) treatment for wheat and canola. Means within a column followed by the same letter are not significantly different $(p<0.05)$.

Table 4. Concentrations of micronutrients $\mathrm{B}, \mathrm{Cu}, \mathrm{Fe}$ and $\mathrm{Mn}$ in edible crop parts after application of $\mathrm{Se}, \mathrm{Zn}$, and I to soil at planting in Trial 1.

\begin{tabular}{ccccccc}
\hline Micronutrients & \multicolumn{6}{c}{ Crops } \\
\cline { 2 - 7 }$\left(\mathbf{m g ~ k g}^{-\mathbf{1}}\right)$ & Wheat & Maize & Soybean & Potato & Canola & Cabbage \\
\hline $\mathrm{B}$ & 1.4 & 1.9 & 29.6 & 4.3 & 14.3 & 28.4 \\
$\mathrm{Cu}$ & 4.5 & 1.8 & 19.7 & 8.3 & 3.3 & 4.2 \\
$\mathrm{Fe}$ & 32.1 & 23.5 & 89.7 & 31.4 & 67.2 & 167.1 \\
$\mathrm{Mn}$ & 45.2 & 4.7 & 25.1 & 5.5 & 36.2 & 76.5 \\
\hline
\end{tabular}

* Data were showed only with $\mathrm{Se}+\mathrm{Zn}+\mathrm{I}$ treatments for all crops in Trial 1. 
Table 5. Effects of foliar application of Se and $\mathrm{Zn}$ on wheat biomass and grain yield in Trial 2.

\begin{tabular}{lcc}
\hline $\begin{array}{c}\text { Treatments } \\
\mathrm{Se}\left(\mathrm{g} \mathrm{ha}^{-1}\right)+\mathrm{Zn}\left(\mathrm{kg} \mathrm{ha}^{-1}\right)\end{array}$ & Biomass $\left(\mathrm{kg} \mathrm{ha}^{-1}\right)$ & Grain yield $\left(\mathrm{kg} \mathrm{ha}^{-1}\right)$ \\
\hline Nil & $10080(13.2)$ & $4182(12.3)$ \\
$4+0.23$ & $8737(8.6)$ & $3658(9.8)$ \\
$20+0.45$ & $9314(6.4)$ & $3950(6.9)$ \\
$30+0.68$ & $10123(10.4)$ & $4278(9.2)$ \\
$46+0.91$ & $9538(9.4)$ & $4080(8.8)$ \\
$60+1.14$ & $9092(14.1)$ & $3846(13.6)$ \\
\hline
\end{tabular}

*There are no significant difference between treatments $(p>0.05)$. Data are showed as means and figures in parentheses are CV\% of four replications for each treatment.

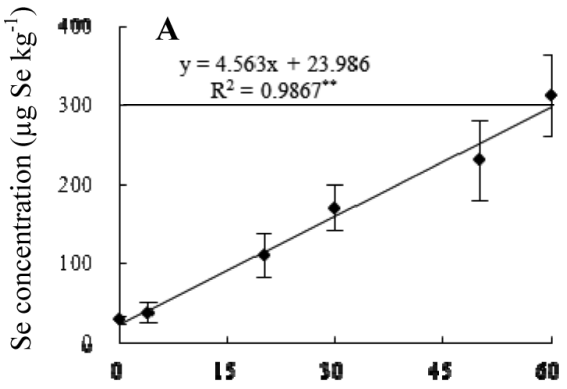

Se rate $\left(\mathrm{g} \mathrm{Se} \mathrm{ha}^{-1}\right)$

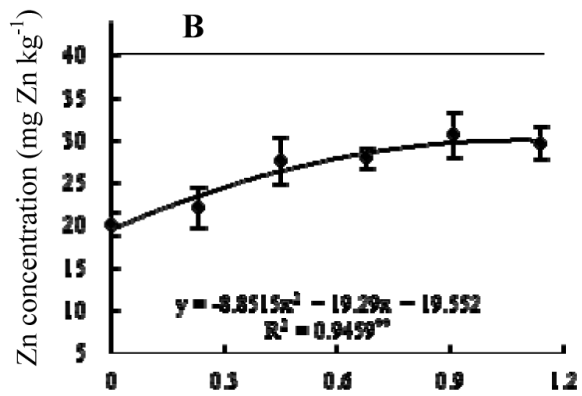

$\mathrm{Zn}$ rate $\left(\mathrm{kg} \mathrm{Zn} \mathrm{ha}{ }^{-1}\right)$

Figure 1. Effects of Se and $\mathrm{Zn}$ foliar applications on Se (A) and $\mathrm{Zn}(\mathrm{B})$ concentrations in wheat grain (vertical bars represent standard errors, the horizontal lines on $\mathrm{A}$ and $\mathrm{B}$ were presented with the target concentrations).

\section{Discussion}

4.1. Crop yield was not remarkably affected by micronutrients

Although some studies have reported increases in biomass from the addition of Se (Turakainen et al., 2004) and I (Dai et al., 2004), these studies were not conducted in the field. The lack of yield response to $\mathrm{Zn}$ (whether soil- or foliar-applied) in the field indicates that the crop yields may be less constrained by the level of available $\mathrm{Zn}$ in the soil here and more dependent on other factors, including low water supply due to local dry climate (Kang et al., 2002). 
4.2. Soil-applied selenate or foliar-applied selenite were effective in increasing selenium concentration in edible parts of crops

The main aim of the trial was to biofortify food crops with key micronutrients. Selenium biofortification was very successful: sodium selenate applied to the soil at planting was efficiently transferred from root to foliage/grain/tuber and was effective for all crops tested. For winter wheat, maize, soybean, potato, canola, and cabbage, the corresponding Se concentration increase with one gram of Se applied per hectare of soil was $17.4,8.6,17.3,10.2,4.1$, and 76.8 $\mu \mathrm{g} \mathrm{kg}^{-1}$, respectively. Therefore, in the experimental area, to reach the biofortification target Se level of 300 $\mu \mathrm{g} \mathrm{kg}^{-1}$, the amount of selenate applied can be reduced to only $16 \mathrm{~g} \mathrm{ha}^{-1}$ for wheat, $34 \mathrm{~g} \mathrm{ha}^{-1}$ for maize, 15 $\mathrm{g} \mathrm{ha}^{-1}$ for soybean, $28 \mathrm{~g} \mathrm{ha}^{-1}$ for potato, $71 \mathrm{~g} \mathrm{ha}^{-1}$ for canola, and $3 \mathrm{~g} \mathrm{ha}^{-1}$ for cabbage. Sodium selenite applied in the same way as selenate was less effective. Application of Se at $1 \mathrm{~g} \mathrm{ha}^{-1}$ in the form of selenite was found to increase the Se concentration by only 0.2 $\mu \mathrm{g} \mathrm{kg}^{-1}$ for maize, $1.2 \mu \mathrm{g} \mathrm{kg}^{-1}$ for soybean, $0.9 \mu \mathrm{g} \mathrm{kg}^{-1}$ for potato, and $605 \mu \mathrm{g} \mathrm{kg}^{-1}$ for cabbage, with the Se biofortification target of $300 \mu \mathrm{g} \mathrm{kg}^{-1}$ reached at 1167 , 213, 331 and $31 \mathrm{~g} \mathrm{ha}^{-1}$, respectively. These findings were consistent with most of the previous studies, which reported that barley grain Se concentration of 100 to $200 \mu \mathrm{g} \mathrm{kg}^{-1}$ was obtained by application of Se at 10 to $20 \mathrm{~g} \mathrm{Se} \mathrm{ha}^{-1}$ as selenate, but over $100 \mathrm{~g} \mathrm{Se}$ $\mathrm{ha}^{-1}$ as selenite was required to reach the same grain $\mathrm{Se}$ level (Yläranta, 1985). On a fine sandy loam soil ( $\mathrm{pH}$ 6.0), the barley grain Se concentration was increased from 33 (control) to $234 \mu \mathrm{g} \mathrm{kg}^{-1}$ with $10 \mathrm{~g} \mathrm{Se} \mathrm{ha}^{-1}$ as selenate, while with the same dose as selenite, no increase for grain Se was found (Gupta et al., 1993).

Foliar application of Se in the form of selenite at rates of 0 to $60 \mathrm{~g} \mathrm{ha}^{-1}$ linearly increased grain Se concentration from $30 \mu \mathrm{g} \mathrm{kg}^{-1}$ to $310 \mu \mathrm{g} \mathrm{kg}^{-1}$, indicating a $4.6 \mu \mathrm{g}$ $\mathrm{kg}^{-1}$ increase of Se concentration in wheat grain for 1 $\mathrm{g} \mathrm{ha}^{-1}$ foliar-applied Se. The grain Se target of $300 \mu \mathrm{g}$ $\mathrm{kg}^{-1}$ was able to be reached using a Se application rate of $59 \mathrm{~g} \mathrm{ha}^{-1}$ for winter wheat. Foliar selenate was not tested in this study, but previous research indicates that selenate is more effective, although the difference is much less than that when the two Se forms are applied to the soil. For rice, the grain Se concentration was also found to be $35.9 \%$ higher with foliar selenate application than with selenite (Chen et al., 2002), and for carrot, its leaves accumulated as much as $80 \mu \mathrm{g}$ Se $\mathrm{g}^{-1}$ (DW) with foliar selenate application, while only $50 \mu \mathrm{g} \mathrm{Se} \mathrm{g}^{-1}$ (DW) with selenite application (Kápolna et al., 2009).

\subsection{Foliar-applied $\mathrm{Zn}$ was more effective than soil- applied Zn for biofortification}

In contrast to $\mathrm{Se}, \mathrm{Zn}$ applied to the soil in the form of $\mathrm{Zn}$ sulphate at a rate of $232.7 \mathrm{~kg} \mathrm{ha}^{-1}$ did not increase $\mathrm{Zn}$ concentrations in the edible parts of any crop, except for cabbage and canola, where a 2-fold increase in cabbage leaf and 0.3-fold increase in canola seed were obtained, and $\mathrm{Zn}$ application of $1 \mathrm{~kg} \mathrm{ha}^{-1}$ increased their $\mathrm{Zn}$ concentration respectively by 0.3 and $1.8 \mathrm{mg} \mathrm{kg}^{-1}$, with the $\mathrm{Zn}$ biofortification target of $40 \mathrm{mg} \mathrm{kg}^{-1}$ reached correspondingly at 40 and 11 $\mathrm{kg} \mathrm{ha}^{-1}$. This result indicates that $\mathrm{Zn}$ application on loess soil is not an effective biofortification method. Another study showed that the application of $5 \mathrm{mg}$ $\mathrm{kg}^{-1} \mathrm{Zn}$ to soil increased the $\mathrm{Zn}$ concentration of navy bean shoot from $19.93 \mathrm{mg} \mathrm{kg}^{-1}$ to $38.12 \mathrm{mg} \mathrm{kg}^{-1}$, and of $10 \mathrm{mg} \mathrm{kg}^{-1} \mathrm{Zn}$, increased that to $54.48 \mathrm{mg} \mathrm{kg}^{-1}$ in a navy bean greenhouse experiment (Gonzalez et al., 2008). The effect of soil $\mathrm{Zn}$ application on the grain $\mathrm{Zn}$ concentration is further related to the soil characteristics that affect $\mathrm{Zn}$ availability, including $\mathrm{pH}$ and $\mathrm{Ca}$ concentration (Alloway, 2009). On the loess soil, low effectiveness of soil-applied $\mathrm{Zn}$ application could be attributed to the adsorption by soil colloids and the limited transport of $\mathrm{Zn}$ absorbed by plants from phloem to grain/tubers (Erenoglu et al., 2011). Compared to soil application, foliar application of $\mathrm{Zn}$ was shown to be a more effective and efficient way to increase $\mathrm{Zn}$ concentration in winter wheat grain, with the maximum grain $\mathrm{Zn}$ of $30 \mathrm{mg} \mathrm{kg}^{-1}$ reached at $1.14 \mathrm{~kg} \mathrm{ha}^{-1}$, although it was still lower than the recommended value of $40 \mathrm{mg} \mathrm{kg}^{-1}$. These results are 
similar to those reported by Yilmaz (Yilmaz et al., 1997) in which foliar-applied $\mathrm{Zn}$ increased wheat grain $\mathrm{Zn}$ concentration by $50 \%$ from 18 to $27 \mathrm{mg} \mathrm{Zn} \mathrm{kg}{ }^{-1}$, and was more effective than soil-applied Zn. Similar findings were described by Cakmak (Cakmak et al., 2010b), which showed wheat grain $\mathrm{Zn}$ concentration was increased from 11.7 (control) to $26.9 \mathrm{mg} \mathrm{kg}^{-1}$ with foliar-applied $\mathrm{Zn}$. Thus, foliar $\mathrm{Zn}$ application is an effective biofortification method for wheat grain on the Loess Plateau.

\subsection{Soil applied I was effective for biofortification of I in leafy vegetables}

Application of I (in the form of potassium iodate) to the soil did not increase I levels in grains of wheat, maize, soybean, canola or in potato tubers, but exhibited a two fold increase in I concentration in cabbage leaf, and I application of $1 \mathrm{~g} \mathrm{ha}^{-1}$ increased the leaf I concentration by $1.1 \mu \mathrm{g} \mathrm{kg}^{-1}$, with the I biofortification target of $500 \mu \mathrm{g} \mathrm{kg}^{-1}$ reached without I application. Iodine levels in grain or seed are usually low, which was also the case in this trial (10-20 $\mu \mathrm{g} \mathrm{kg}$ $\left.{ }^{1}\right)$, and in potato tubers it was slightly higher at around $60 \mu \mathrm{g} \mathrm{kg}^{-1}$, but in the canola seed, the I level was around $1000 \mu \mathrm{g} \mathrm{kg}^{-1}$. Other researchers found that I levels in rice leaves were over $100 \mathrm{mg} \mathrm{kg}^{-1}$, but only 10 $\mathrm{mg} \mathrm{kg}^{-1}$ in grain with an application of $100 \mathrm{\mu M} \mathrm{IO}_{3}^{-1}$. The reason for this may be that I is transported almost entirely in the xylem, and that only a minimal amount is loaded into the grain/seed or tubers (Mackowiak and Grossl, 1999). The control cabbage leaves had a higher I concentration $\left(580 \mu \mathrm{g} \mathrm{kg}^{-1}\right)$ than the target I level of $500 \mu \mathrm{g} \mathrm{kg}^{-1}$, estimated from the recommended I consumption of $150 \mu \mathrm{g} \mathrm{d}^{-1}$ for adults by Mackowiak and Grossl (Mackowiak and Grossl, 1999).

Thus, increasing the dietary I content by agronomic biofortification of leafy vegetables such as cabbage, lettuce, and spinach may be relatively easy. For regions such as Yongshou, Shaanxi Province, where these trials were conducted, the best approach to increase human I levels is to encourage greater consumption of leafy vegetables.

\section{Conclusion}

Using a range of food crops in field trials in the Loess Plateau, which has a dry climate and low soil nutrient availability, soil-applied selenate and foliar-applied selenite were found to be effective for Se biofortification. Foliar zinc sulphate is effective in biofortifying winter wheat, and soil-applied $\mathrm{Zn}$ is effective in increasing the $\mathrm{Zn}$ concentration in cabbage leaf and canola seed. Soil-applied I was found to be only effective in increasing I concentration in cabbage leaf. Agronomic biofortification of the crops with $\mathrm{Se}$ as soil-applied sodium selenate was unaffected by co-application of $\mathrm{Zn}$ and/or I.

\section{Acknowledgements}

We gratefully acknowledge the HarvestPlus Biofortification Challenge Program (www.harvestplus. org), the International Fertilizer Industry Association (IFA), the National Natural Science Foundation of China (30871596, 41201280), the National Key Basic Research Special Funds (2009CB118604), and the Innovative Research Team Program of Northwest A\&F University. We also acknowledge the expert assistance of Teresa Fowles and Lyndon Palmer (Waite Analytical Services, University of Adelaide) and the testing centre of the Resources and Environmental College of Northwest Agricultural and Forestry University for mineral analyses.

\section{References}

Alloway, B. 2009. Soil factors associated with zinc deficiency in crops and humans. Environ. Geochem. Health. 31, 537-548.

Bawa, S., Dhillon, K., Dhillon, S. 1992. Screening of different fodders for selenium absorption capacity. Indian J. Dairy Sci. 45, 457-457. 
Brown, K.H., Wuehler, S.E., Peerson, J.M. 2001. The importance of zinc in human nutrition and estimation of the global prevalence of zinc deficiency. Food \& Nutr. Bull. 22, 113-125.

Cakmak, I. 2008. Enrichment of cereal grains with zinc: agronomic or genetic biofortification?. Plant Soil. 302, 1-17.

Cakmak, I., Kalayci, M., Kaya, Y., Torun, A., Aydin, N., Wang, Y., Arisoy, Z., Erdem, H., Yazici, A., Gokmen, O. 2010a. Biofortification and localization of zinc in wheat grain. J. Agr. Food Chem. 58, 9092-9102.

Cakmak, I., Pfeiffer, W.H., McClafferty, B. 2010b. Review: Biofortification of durum wheat with zinc and iron. Cereal Chem. 87, 10-20.

Cao, X.Y., Jiang, X.M., Dou, Z., Rakeman, M.A., Kareem, A., Zang, M., Ma, T., O'Donnell, K., DeLong, N., DeLong, G. 1994. Iodination of irrigation water as a method of supplying iodine to a severely iodine-deficient population in Xinjiang, China. The Lancet. 344, 107-110.

Chen, L., Yang, F., Xu, J., Hu, Y., Hu, Q., Zhang, Y., Pan, G. 2002. Determination of selenium concentration of rice in China and effect of fertilization of selenite and selenate on selenium content of rice. J. Agr. Food Chem. 50, 5128-5130.

Dai, J.L., Zhu, Y.G., Zhang, M., Huang, Y.Z. 2004. Selecting iodine-enriched vegetables and the residual effect of iodate application to soil. Biol. Trace. Elem. Res. 101, 265-276.

Erenoglu, E.B., Kutman, U.B., Ceylan, Y., Yildiz, B., Cakmak, I. 2011. Improved nitrogen nutrition enhances root uptake, root to shoot translocation and remobilization of zinc $\left({ }^{65} \mathrm{Zn}\right)$ in wheat. New Phytol. 189, 438-448.

Ercoli, L., Lulli, L., Arduini, I., Mariotti, M., Masoni, A. 2011. Durum wheat grain yield and quality as affected by $\mathrm{S}$ rate under Mediterranean conditions. European J. Agron. 35, 63-70.

Gonzalez, D., Obrador, A., Lopez-Valdivia, L., Alvarez, J. 2008. Effect of zinc source applied to soils on its availability to navy bean. Soil Sci. Soc. Am. J. 72, 641-649.

Gupta, U.C., Winter, K., Sanderson, J. 1993. Selenium content of barley as influenced by selenite and selenate-enriched fertilizers. Commun. Soil Sci. Plant Anal. 24, 1165-1170.

Hasani, M., Zamani, Z., Savaghebi, G., Fatahi, R. 2012. Effects of zinc and manganese as foliar spray on pomegranate yield, fruit quality and leaf minerals. J. Soil Sci. Plant Nutr. 12, 471-480.

Kápolna, E., Hillestrøm, P. R., Laursen, K. H., Husted, S., Larsen, E. H. 2009. Effect of foliar application of selenium on its uptake and speciation in carrot. Food Chem. 115, 1357-1363.

Kang, S., Zhang, L., Liang, Y., Hu, X., Cai, H., Gu, B. 2002. Effects of limited irrigation on yield and water use efficiency of winter wheat in the Loess Plateau of China. Agr. Water Manage. 55, 203-216.

Liu, Z. 1994. Regularities of content and distribution of zinc in soils of China. Scientia Agricutura Sinica. 27, 30-37.(in Chinese)

Lyons, G., Ortiz-Monasterio, I., Stangoulis, J., Graham, R. 2005a. Selenium concentration in wheat grain: Is there sufficient genotypic variation to use in breeding?. Plant Soil. 269, 369-380.

Lyons, G.H., Judson, G.J., Ortiz-Monasterio, I., Genc, Y., Stangoulis, J.C., Graham, R.D. 2005b. Selenium in Australia: selenium status and biofortification of wheat for better health. J. Trace. Elem. Med. Bio. 19, 75-82.

Mackowiak, C., Grossl, P. 1999. Iodate and iodide effects on iodine uptake and partitioning in rice 
(Oryza sativa L.) grown in solution culture. Plant Soil. 212, 133-141.

Mayer, J.E., Pfeiffer, W.H., Beyer, P. 2008. Biofortified crops to alleviate micronutrient malnutrition. Curr. Opin. Plant Biol. 11, 166-170.

Prasad, A.S. 2009. Impact of the discovery of human zinc deficiency on health. J. Am. Coll. Nutr. 28, 257-265.

Tan, J. 2004 Geological environment and health. Chemical Industry Press, Beijing, China

Turakainen, M., Hartikainen, H., Seppänen, M.M. 2004. Effects of selenium treatments on potato (Solanum tuberosum L.) growth and concentrations of soluble sugars and starch. J. Agr. Food Chem. $52,5378-5382$.

Wang, J., Mao, H., Zhao, H., Huang, D., Wang, Z. 2012. Different increases in maize and wheat grain zinc concentrations caused by soil and foliar applications of zinc in Loess Plateau, China. Field. Crop. Res. 135, 89-96.

White, P. J., Broadley, M. R. 2005. Biofortifying crops with essential mineral elements. Trends Plant Sci. $10,586-593$.
White, P.J., Broadley, M.R. 2009. Biofortification of crops with seven mineral elements often lacking in human diets-iron, zinc, copper, calcium, magnesium, selenium and iodine. New Phytol. $182,49-84$

Yang, X., Chen, W., Feng, Y. 2007. Improving human micronutrient nutrition through biofortification in the soil-plant system: China as a case study. Environ. Geochem. Health. 29, 413-428.

Yilmaz, A., Ekiz, H., Torun, B., Gultekin, I., Karanlik, S., Bagci, S., Cakmak, I. 1997. Effect of different zinc application methods on grain yield and zinc concentration in wheat cultivars grown on zincdeficient calcareous soils. J. Plant Nutr. 20, 461471.

Yläranta, T. 1985. Increasing the selenium content of cereals and grass crops in Finland. Academic dissertation. Faculty of Agriculture and Forestry, University of Helsinki, 72p.

Zarcinas, B., Cartwright, B., Spouncer, L. 1987. Nitric acid digestion and multi-element analysis of plant material by inductively coupled plasma spectrometry. Commun. Soil Sci. Plant Anal. 18, 131-146. 